\title{
Lymphocyte Proliferation and Nitric Oxide-Producing Activities of Lupeol Isolated From Red Dragon Fruit (Hylocereus polyrhizus) Extract
}

\author{
Sri Wahdaningsih ${ }^{1}$, Subagus Wahyuono², Sugeng Riyanto², Retno Murwanti² \\ ${ }^{1}$ Department of Pharmacy, Faculty of Medicine, Universitas Tanjungpura, Pontianak, Indonesia \\ ${ }^{2}$ Faculty of Pharmacy, Universitas Gadjah Mada, Yogyakarta, Indonesia
}

Background: Hylocereus polyrhizus has activities as antimicrobial agent, anti-hypercholesterolemia, anti-diabetic (diabetes mellitus), cardiovascular risk reduction, health supplement, and melanoma cell suppression. The extracts from the peels of H. polyrhizus were able to increase phagocytic ability, cell numbers and leukocytes and to influence relative spleen weights in the formation of body immune system in male rats. The fruit peels contained phenolics, flavonoids, carotenoids, and anthocyanins. This study investigated the active compounds of $H$. polyrhizus peels, which are able to increase immune system of human body.

Materials and method: In vitro assay was applied to examine the active compounds, identified as lupeol, obtained from isolated extract of red dragon fruit for their lymphocyte proliferation and nitric oxide (NO)-producing activities. Lymphocyte proliferation assay was performed with 3-4.5-dimethylthiazol-2-yl)-2.5-diphenyltetrazolium bromide (MTT) method. The cell control was lymphocyte cell suspension in RPMI medium added with phytohaemaglutinine (PHA). The NO measurement was conducted with nitric solvent and Greiss reagent.

Results: The ANOVA analysis of the average optical density (OD) of lymphocyte proliferation showed that the addition of isolated lupeol at the concentrations of $6.25,12.5,25,50$ and $100 \mu \mathrm{g} / \mathrm{mL}$ were able to improve lymphocyte proliferation and activate the NO production in the rats with treatment of positive control.

Conclusion: Isolated lupeol at concentrations of $6.25,12.5,25,50$ and $100 \mu \mathrm{g} / \mathrm{mL}$ revealed significant difference with medium control and cell control. It was able to increase effects on lymphocyte proliferation and NO production. Therefore, the lupeol which was isolated might have high potential to be an immunostimulant.

Keywords: Hylocereus polyrhizus, lupeol, lymphocyte proliferation, nitric oxide production

\section{Introduction}

The peels of red dragon fruit (Hylocereus polyrhizus) are rich of natural antioxidant compounds including phenolics, flavonoids, carotenoids, and anthocyanins. ${ }^{1}$ The peels of red dragon fruit produced higher anthocyanins (22.6 $\mu \mathrm{g} / \mathrm{mL})$ than of white dragon fruit did $(16.7 \mu \mathrm{g} / \mathrm{mL})$. Antioxidant activities of methanol extract, ethyl acetate

Date of submission: May 28, 2020

Last Revised: July 23, 2020

Accepted for publication: July 28, 2020

Corresponding Author:

Sri Wahdaningsih

Department of Pharmacy, Faculty of Medicine

Universitas Tanjungpura, Jl. Profesor Dokter Haji Hadari Nawawi

Pontianak 78115, Indonesia

e-mail: wahdanieanie@gmail.com

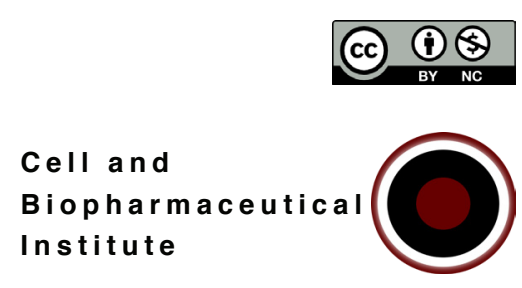


soluble fraction, and ethyl acetate insoluble fraction were $241.19,8.34$ and $46.84 \mu \mathrm{g} / \mathrm{mL}$ respectively.,3 The antioxidant activity of isolated lupeol of red dragon fruit peel extracts was $2.95214 \mu \mathrm{g} / \mathrm{mL} .{ }^{4}$ Immune system of body needs antioxidant nutrients to produce and keep the balance of immune cells (hematopoiesis), protect cell membranes against superoxide radical (SOR) (vitamins and minerals as antioxidants), and defend against pathogens (innate immune and adaptive immune). The diseases caused by reactive oxygen species (ROS) involved rheumatoid arthritis (RA), hemorrhagic stroke, cardiovascular, metabolism disorder, neurodegenerative disease, gastrointestinal diseases, acquired immune deficiency syndrome (AIDS), etc. ${ }^{5}$ Immunomodulator is a substance that can either affect or change immune response in the body. Immune system of body consists of innate and adaptive immune with a complex system involving biochemical mechanism. Partitions of methanol extracts of red dragon fruit peels using petroleum ether improved the macrophage phagocytic activity. ${ }^{6}$ This study, however, investigated lymphocyte proliferation and nitric oxide (NO)-producing activities of the active compounds of $H$. polyrhizus peels, which are able to increase immune system of human body.

\section{Materials and methods}

The sample was lupeol isolated from the peels of red dragon fruits which were obtained from Bantul, Yogyakarta. The research was conducted at the Parasitology Laboratory, Universitas Gadjah Mada, Yogyakarta.

\section{Lymphocyte Proliferation Assay}

Lymphocytes of Balb/C mice spleen cells were isolated. Firstly, the mice were anesthetized using chloroform, and were dissected for their spleen tissue. The tissue was then isolated aseptically and put on $50 \mathrm{~mm}$ petri dish added with $10 \mathrm{~mL}$ RPMI medium. The tissue was lysed by inflating RPMI medium into the spleen so that lymphocytes spilled with the medium. The cell suspension was put into a $10 \mathrm{~mL}$ centrifuge tube and was centrifuged at $3000 \mathrm{rpm} 4^{\circ} \mathrm{C}$ for 5 minutes. The resulted pellet was suspended in $5 \mathrm{~mL}$ trisbuffered ammonium chloride to lysis erythrocytes. The cells were mixed to get homogenous and were set aside at room temperature for 15 minutes or till the color changed into yellowish. As much as $10 \mathrm{~mL}$ RPMI ad was then added and centrifuged at $3000 \mathrm{rpm} 4^{\circ} \mathrm{C}$ for 5 minutes; the supernatant was removed. The resulted pellet was washed twice using RPMI. The cells were counted with hemocytometer. The lymphocyte cells were ready to culture in a $\mathrm{CO}_{2}$ incubator at concentration of $5 \%$ at temperature of $37^{\circ} \mathrm{C}$ and were ready to be tested for their activities.?

\section{Lymphocyte Proliferation Assay with MTT Method}

As much as $1.5 \times 10^{6} / \mathrm{mL}$ of $100 \mu \mathrm{L}$ lymphocytes were distributed into 96-wells microplate and incubated for 24 hours in $\mathrm{CO}_{2}$ incubator at concentration of $5 \%$ at $37^{\circ} \mathrm{C}$. Then $100 \mu \mathrm{L}$ samples were added at concentrations of $6.25,12.5$, 25, 50 and $100 \mu \mathrm{g} / \mathrm{mL} ; 100 \mu \mathrm{L}$ PHA, a positive control, was added at concentration of $10 \mu \mathrm{L}$ and then incubated again for 48 hours. Each well was then added with $5 \mathrm{mg} /$ $\mathrm{mL}$ of $10 \mu \mathrm{L}$ MTT solution and was incubated again at temperature of $37^{\circ} \mathrm{C}$ for 4 hours. The living lymphocytes reacted with MTT resulting in purple color. The reaction was stopped using 10\% stopper reagent, Sodium Dodecyl Sulfate (SDS) in $0.01 \mathrm{~N}$ chlorine acid $(100 \mu \mathrm{L})$ in each well and set aside for 24 hours. Furthermore, the absorption was measured using microplate reader at the wavelength of $550 \mathrm{~nm}^{8}$

\section{NO Measurement}

Sixty-nine mg of natrium nitrite was dissolved in $100 \mathrm{~mL}$ sterilized water to obtain solution stock of $2000 \mu \mathrm{M}$ standard nitrite and was kept at temperature of $0-4^{\circ} \mathrm{C}$ and protected from light. Standard solution of nitrite was prepared for series of solution concentration at the range of $0-100$ $\mu \mathrm{M}$. The varied solutions were added into 96-multiwell plate, $100 \mu \mathrm{L}$ per well; the incubated macrophage cultures obtained from macrophage isolation procedure as explained were added with $100 \mu \mathrm{L}$ Greiss reagent which consisted of Griess A containing $0.5 \mathrm{~g}$ of sulfanilic acid and 150 $\mathrm{mL}$ of $30 \% \mathrm{v} / \mathrm{v}$ acetic acid and Griess B containing $0.1 \mathrm{~g}$ of naphthyl ethylenediamine in $20 \mathrm{~mL}$ sterilized water and $150 \mathrm{~mL}$ glacial acetic acid with ration of 1:1 in each well. The incubation was at room temperature for 15 minutes, and its absorption was read using microplate reader at the wavelength of $595 \mathrm{~nm} .^{9}$

\section{Data Analysis}

The results of phagocytosis were tested for their homogeneity and distribution using Shapiro-Wilk. When it was normal distribution, one way ANOVA test was applied, continued with LSD analysis to $95 \%$ confidence to determine the difference among the treatment groups. The data were analyzed with SPSS program ver. 22 (IBM Corporation, New York, USA). 


\section{Results}

The assay was performed using MTT method. The optical density (OD) data of lymphocyte proliferation were analyzed statistically. The addition of isolated lupeol at concentrations of $6.25,2.5,25,50$ and $100 \mu \mathrm{g} / \mathrm{mL}$ were able to increase lymphocyte proliferation compared to media control and cell control (Figure 1).

The activation of NO product in mice given positive stimulant control and different isolation treatments differed from the mice in control cell (Figure 2). The activation of NO product in mice given isolated lupeol at concentration of $100 \mu \mathrm{g} / \mathrm{mL}$ and ST at concentration of $6.25 \mu \mathrm{g} / \mathrm{mL}$ resulted in NO product which was the same as of given positive stimulant.

\section{Discussion}

Lymphocyte proliferation assay is a method applied to measure the capability of lymphocyte to proliferate. The proliferation response of lymphocyte cultures were used to explain the functions of lymphocytes and status of body immune. ${ }^{10}$ The lymphocytes were isolated from spleen tissue of Balb/C mice; spleen was used as it is the main secondary lymphoid organ containing T-cell and B-cell. ${ }^{11}$ The statistical analysis of average OD, using ANOVA, showed that the addition of isolated lupeol at concentrations of $6.25,2.5,25,50$ and $100 \mu \mathrm{g} / \mathrm{mL}$ was able to increase lymphocyte proliferation. Based on previous study, fruit and peel of Hylocereus undatus extracts showed that extracts with increased concentration would increase the rate of lymphocyte proliferation. Higher concentration range of $2000 \mu \mathrm{g} / \mathrm{mL}$ peel methanolic extracts showed higher proliferation rate of $251.16 \%{ }^{16}$

The general mechanism of lymphocyte proliferation process was due to active compound (antigen) bounded over T-cell and B-cell membranes. Lymphocyte is the main cell that functions in responding adaptive immune. The cell is categorized into T-cell, B lymphocyte and NK cell. Lymphocyte proliferation is a mechanism of lymphocyte in synthesizing DNA after cross-linking by antigen receptors, through either antigen presentation or polyclonal activator stimulation. Proliferation occured through bounding over T-cell receptor (TCR) of the complex peptide-MHC by APC along with stimulation signals delivered through the interaction between CD28 and its ligands. ${ }^{7}$ Stimulated T-cell of lymphocyte would produce cytokinins in the form of interferon- $\gamma$ (IFN- $\gamma)$, interleukin-1 (IL-1), and interleukin-2 (IL-2). ${ }^{10}$

Isolated lupeol with a concentration of $100 \mu \mathrm{g} / \mathrm{mL}$ has NO of 3.04 which is not much different from ST with a concentration of 6.25 which has $\mathrm{NO}$ of 3.33 . Isolated lupeol at concentrations of $6.25,12.5,25,50$ and $100 \mu \mathrm{g} /$ $\mathrm{mL}$ significantly different with media control and able to increase NO production. NO is an arginine reaction product catalyzed using inducible oxide synthase (iNOS) enzyme. The enzyme and ROS were activated during phagolysosome

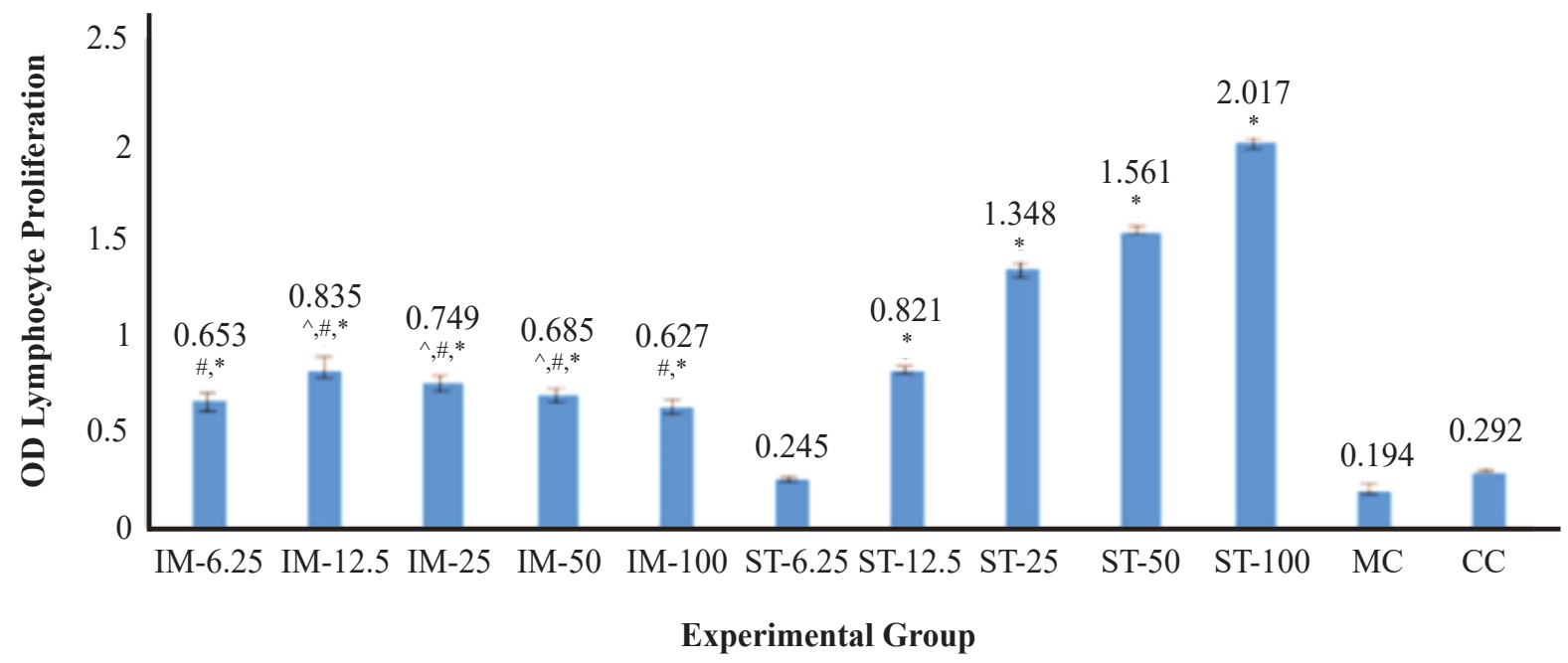

Figure 1. Lymphocyte proliferation of isolated lupeol. IM: isolate 1 at concentrations of $6.25,12.5,25,50$ and $100 \mu \mathrm{g} / \mathrm{mL}$; ST: stimuno at concentrations of $6.25,12.5,25,50$ and $100 \mu \mathrm{g} / \mathrm{mL}$; MC: medium control; CC: cell control. *: significantly different with MC and CC; \#: significantly different with $\mathrm{ST}^{\wedge}{ }^{\wedge}$ : significantly different with IM $100 \mu \mathrm{g} / \mathrm{mL}$. 


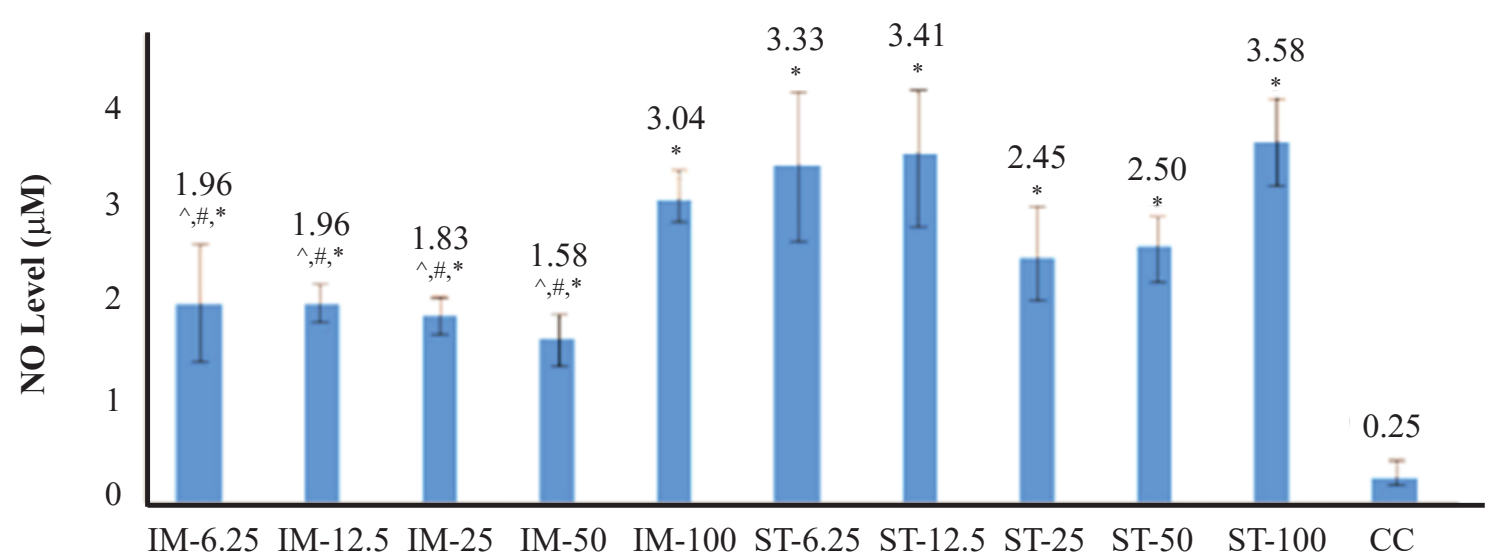

Experimental Group

Figure 2. Effect of isolated lupeol addition on the activity of nitric oxide production. IM: isolate 1 at concentrations of $6.25,12.5,25,50$ and $100 \mu \mathrm{g} / \mathrm{mL}$; ST: stimuno at concentrations of $6.25,12.5,25,50$ and $100 \mu \mathrm{g} / \mathrm{mL}$; CC: cell control. *: significantly different with medium control; \#: significantly different with IM 100; ${ }^{\wedge}$ : significantly different with ST.

process. ${ }^{11}$ In reasonable amount, NO had physiological functions of signaling process in cells and controlling inflammation. ${ }^{12} \mathrm{NO}$ collaborated with macrophage lysosome to kill phatogens such as bacteria, fungi, and virus in phagocytosis process. ${ }^{13} \mathrm{NO}$ could damage cell that produce NO itself and cell surrounding; this enabled the reduced NO level despite the high phagocytosis. ${ }^{11}$ The high macrophage phagocytosis activity without excessive NO production was assumed to be resulted from the compounds in the sample that could keep the functions of immune cells by protecting the macrophage against excessive phagocytosis. ${ }^{14}$ The excessive production of $\mathrm{NO}$ was able to activate guanylate cyclase enzyme that could result in negative effects such as induction of protein causing stress and damaged DNA. ${ }^{15}$

\section{Conclusion}

Isolated lupeol at concentrations of $6.25,12.5,25,50$ and $100 \mu \mathrm{g} / \mathrm{mL}$ revealed significant difference with media control and cell control; it was able to increase effects on lymphocyte proliferation and nitric oxide production. Therefore, the lupeol which was isolated might have high potential to be an immunostimulant.

\section{Acknowledgements}

Authors would like to thank to all of students who participated in this study.

\section{References}

1. Handayani PA, Rahmawati A. Pemanfaatan kulit buah naga (dragon fruit) sebagai pewarna alami makanan pengganti pewarna sintetis. Jurnal Bahan Alam Terbarukan. 2012; 1(2): 19-24.

2. Wahdaningsih S, Wahyuono S, Riyanto S, Murwanti R. The radical scavenging activity of 2-2' diphenyl -1- picrylhydrazil (dpph) on the methanol extracts and ethyl acetate fractions of red dragon fruit peel (Hylocereus polyrhizus (F.A.C.Weber) Britton dan Rose). Int J Phytomedicine. 2017; 9(1): 79-82.

3. Wahdaningsih S, Wahyuono S, Riyanto R, Murwanti R. Penetapan kadar fenolik total dan flavonoid total ekstrak metanol dan fraksi etil asetat kulit buah naga merah (Hylocereus polyrhizus (F.A.C.Weber) Britton dan Rose). PHARMACON Jurnal Ilmiah Farmasi. 2017; 6(3): 295-301.

4. Wahdaningsih S, Wahyuono S, Riyanto R, Murwanti R. Antioxidant activity of red dragon fruit peel (Hylocereus polyrhizus (F.A.C.Weber) Britton and Rose) isolates using DPPH method. Asian J Pharm Clin Res. 2018; 11(1): 124-8.

5. Aher VD, Wahi A, Pawdey AM, Sonawane A. Antioxidant as immunomodulator : an expanding research avenue. Int $\mathrm{J}$ Curr Pharm Res. 2011; 3(1): 8-10.

6. Wahdaningsih S, Wahyuono S, Riyanto R, Murwanti R. In vitro test of macrophage phagocytic activity of extracts and fractions of red dragon fruit peel (Hylocereus polyrhizus (F.A.C.Weber) Britton and Rose). Dhaka Univ J Pharm Sci. 2018; 17 (2): 161-5.

7. Descotes J. Principles and Methods of Immunotoxicology. Philadelphia: Elsevier; 2004.

8. Hay FC, Westwood OMR. Practical Immunology. 4th ed. Oxford; Blackwell Science; 2002.

9. Titheradge MA. The enzymatic measurement of nitrate and nitrite. In: Nitric Oxide Protocols. Totowa: Humana Press Inc; 1998. p.83-92.

10. Roitt IM. Essential Immunology. 9th edition. London; University Collage Medical School; 1997. 
11. Abbas AK, Lichtman AH, Pillai S. Cellular and Moleculer Immunology. 6th ed. Philadelphia: Saunders Elsevier; 2007.

12. Giordano D, Li C, Suthar MS, Draves KE, Ma DY, Gale M, et al. Nitric oxide controls an inflammatory-like Ly6C(hi)PDCA1+DC subset that regulates Th 1 immune responses. J Leukoc Biol. 2011; 89(3): 443-55.

13. Baratawidjaja KG, Rengganis I. Imunologi Dasar. 11th edition. Jakarta: Balai Penerbit Fakultas Kedokteran Universitas Indonesia; 2014.
14. Hartini YS, Wahyuono S, Widyarini S, Yuswanto A. In vivo immunodulatory effect and histophatological features of mouse liver and kidney treated with neolignans isolated from red betel (Piper crocatum Ruiz \& Pav.) Trop J Pharm Res. 2014; 13(10): 1609-14.

15. Devlin TM. Biochemistry with Clinical Correlation. 5th ed. New York; Wiley-Liss; 2002.

16. Harithpriya K, Jeyachandran R. In-vitro immunomodulatory activity of dragon fruit extract. Int J Pharma Bio Sci. 2019; 10(3): 99-106. 